\title{
Antibacterial Effect of Plantago Ovata and Lallemantia Iberica Seed Extracts against Some Bacteria
}

\author{
Leila Karami ${ }^{1}$, Najmeh Ghahtan ${ }^{2}$, Hassan Habibi ${ }^{{ }^{*}}$ \\ ${ }^{1}$ Agriculture and natural resource college, Persian Gulf University, Bushehr, Iran. \\ ${ }^{2}$ Department of horticultural sciences, Faculty of Agriculture, Persian Gulf University, Bushehr, Iran.
}

Received: 3 Jul 2017

Revised : 17 Aug 2017

Accepted: 25 Aug 2017

Corresponding Author: Hassan Habibi

Assistant professor of Agriculture and natural sciences college, Persian Gulf University, Bushehr, Iran.

Phone: +98-9173034921

E-mail: H.habibi@pgu.ac.ir

\begin{abstract}
Background: Researchers are seeking new plant compounds as an alternative to chemical drugs and antibiotics due to the increasing resistance of pathogenic bacteria to antibiotics. This study investigated the antibacterial effect of Plantago ovata and Lallemantia iberica L. seed extracts on some foodborne human pathogenic bacteria.

Materials and Methods: Disk-diffusion antibiotic sensitivity testing, Minimum Inhibitory Concentration (MIC) and Minimum Bactericidal Concentration (MBC) were used to evaluate the antibacterial activity of plant extracts in comparison to the tetracycline, as a control antibiotic.

Results: The results of this experiment showed that the L. iberica seed extract had the greatest effect on Bacillus subtilis, Bacillus sphaericus and Pseudomonas aeruginosa and did not have inhibitory effect or moderate inhibitory effect against other bacteria. Also, P. ovata extract had a high and moderate effect against Bacillus sphaericus and Pseudomonas aeruginosa, respectively. This extract had no inhibitory effect on the other bacteria. Tetracycline also had a significant inhibitory effect on all tested bacteria.

Conclusion: According to the results of this study, it can be concluded that extracts of some Iranian native plants can be a suitable alternative to the existing antibiotics.
\end{abstract}

Keywords: Medicinal plants; Disk diffusion; Plantago ovate; Lallemantia iberica L

Please cite this article as: Karami L, Ghahtan N, Habibi H. Antibacterial Effect of Plantago Ovata and Lallemantia Iberica Seed Extracts against Some Bacteria. Res Mol Med, 2017; 5(3): 32-36

\section{Introduction}

Bacteria resistant to antibiotics have been reported worldwide (1). These bacteria influence human digestive system by infected meats (2). Bacillus species are gram-positive, rod-shaped, aerobic or anaerobic bacteria which are found abundantly in water and soil. These bacteria also cause food poisoning and secondary infections. Bacillus cereus more frequently contaminates milk and meat and in this way enters the human body $(3,4)$. Pseudomonas is a gram-negative and aerobic bacterium and has the ability to grow in most environments (5). The bacteria from this group not only cause disease in animals, but also cause secondary infections in humans (6). The bacterial resistance to antibiotics has become a major clinical and public health problem in recent years (10).Given the ever growing human population, the increasing demand or a greater diversity of healthy food is becoming increasingly a growing issue. On the other hand, the use of unauthorized chemicals and all kinds of antibiotics in various animal derived protein products such as milk, meat, eggs and other types of proteins has increased dramatically over the last few years (8). These foods cause health problems, mental illnesses and various types of diseases such as allergy, cancer, digestive problems and different types of genetic disorders in human societies (8). The excessive use of antibiotics can cause gastrointestinal resistant to these compounds and may lead to antibiotic-associated diarrhea (9). As the use of antibiotics in animals is the main reason of antimicrobial resistance promotion in humans, these trends in the antibiotic resistance may be reversed by switching to the production of organic food (10). The use of antibiotic 
has been banned in the European Union since January 2006. So, scientists have become interested in evaluating other alternatives to control specific microbial populations to modulate rumen fermentation (8). Nowadays, herbal plants are used on a large-scale in medicine against drug-resistant bacteria, which are considered as one of the most important reasons for the lack of success in the treatment of infectious diseases. Herbal plants are the major sources of new medicines and may be considered as an alternative to the usual drugs (11).

Plantago ovata and Lallemantia iberica L . contain a lot of mucilage and oils. The $P$. ovata leaves are glabrous and elliptical; its seeds are transparent, pinkish-gray to brown, or white to pink (12). P. ovata is a member of Plantaginaceae family and is native to Iran and India (13). The seeds of this plant contain 20-30\% mucilage, which produces D-xylosan, arabinose, D-galactose, and D-galacturonic acid by hydrolysis process (14). P. ovata is one of the most important medicinal plants that have been used since ancient times for various reasons in Iran and have high antibacterial properties. Its effect on various bacteria, including Staphylococcus aureus, $S$. pyogenes and Bordetella bronchiseptica has been determined (15). P. ovata seeds have been added to breakfast cereal in various countries such as United States, Canada and Australia, to increase the dietary fiber content and to decrease blood cholesterol. It should be noted that it sometimes causes allergies and anaphylaxis (13).

L. iberica contains compounds such as $\beta$-Cubebene, Linalool and Spathulenol. It is notable that this medicinal herb has a strong antioxidant effect (16).

In the present study, we have evaluated the antibacterial effects of $L$. iberica and $P$. ovata seed extracts on some human pathogenic bacteria capable of causing human illness and food spoilage.

\section{Materials and methods}

The seeds of plants were collected from their natural habitat in Bushehr province, located in the south of Iran, and then dried in a dry and dark environment. These dried seeds were also pulverized to give seed powder (15).

\section{Extraction}

Hydro-alcoholic extract (ethanol 70\%) was prepared by seed soaking for 48 hours at room temperature and then filtered with filter paper (15). The following oils were used: Plantago ovata and Lallemantia iberica $L$. Species and genus of plants were diagnosed by expert Botanist.

Antimicrobial assay

Agar gel disk diffusion test, minimum inhibitory concentration (MIC) and minimum bactericidal concentration (MBC) were used in this study.

Disk diffusion antibiotic sensitivity testing

The standard bacterial strains including Pseudomonas aeruginosa, P. fluorescence, Bacillus subtilis, $B$. antheracoid, B. coagulanse, B. cereus, B. sphericus, Escherchia coli 0157, Salmonella liatica and $S$. typhymorium ATCC3598 were obtained from the Department of Microbiology at the Schoolof Veterinary Science of Shiraz University in order to investigate the antibacterial properties of the plant extracts. A bacterial suspension with a concentration of $1.5 \times 10^{6}$ CFU. $\mathrm{ml}^{-1}$ was prepared for this test. Also, disk diffusion method was used in order to study the antibacterial activity of the plants. The bacterial suspension was grown on an agar medium, and then the prepared discs were placed on a bacterial culture medium. The tetracycline disk was used as a control. The treated Petri dishes were incubated at $37{ }^{\circ} \mathrm{C}$ for $24 \mathrm{~h}$. The diameter of inhibition zone was measured and reported in millimeters (three replications each extract) (17).

Minimum Inhibitory Concentration (MIC) and Minimum Bactericidal Concentration (MBC)

To determine the MIC and MBC, a set of 9 sterile test tubes was used for each extract. The stock solutions $(500 \mathrm{mg} / \mathrm{ml})$ were further diluted in a 2 -fold serial dilution to obtain the following concentrations: $250,125,62.5,31.25,15.625,7.8125,3.91,1.95$ and $0.98 \mathrm{mg} / \mathrm{ml}$. One test tube as a negative control and tetracycline as a positive control were used. An aliquot of $1 \mathrm{ml}$ of the bacterial suspension was inoculated into each tube. The negative control tubes were inoculated with the same quantity of extracts. All tubes were incubated at $37^{\circ} \mathrm{C}$ for $24 \mathrm{~h}$. The lowest concentration that did not permit any visible growth when compared with the control was considered as the minimum inhibitory concentration (MIC). The contents of all tubes that showed no visible growth were cultured on Muller Hinton agar and incubated at $37^{\circ} \mathrm{C}$ for $24 \mathrm{~h}$.The MIC was considered as the lowest concentration that could not produce a single bacterial colony and the MBC was defined as the lowest concentration of the extract at which $99.9 \%$ of the inoculated microorganisms were killed (18).

\section{Statistical analysis}

In order to determine whether there is a statistically significant difference among the obtained results from zone inhibition assays, MIC and MBC average analyses were carried out using the SPSS V16.0. The differences between any means were tested by the Duncan test and the results were considered significant when $\mathrm{P}<0.05$ (19). 


\section{Results}

According to the previous studies, the zone of inhibition ranging $\geq 15 \mathrm{~mm}, 10-15 \mathrm{~mm}$ and $<10 \mathrm{~mm}$ diameter are considered as high, moderate and low antibacterial effect of the essential oils or extracts, respectively [20]. Our results in this experiment showed that the seed extract of $L$. iberica had a high antibacterial effect against $P$. aeruginosa, $B$. subtilis and B. sphericus. This extract also had a moderate effect against $S$. typhymorium ATCC3598 and $B$. cereus. It is notable that other bacteria were not affected by $L$. iberica seed extract. Also, P. ovata seed extract had high and moderate antibacterial effect against $B$. sphericus and $P$. aeruginosa, respectively (Table 1). Tetracycline, as a control group, had remarkable effects against all tested bacteria (Table 1).

Table 1. The inhibition zone $(\mathrm{mm})$ of selected herbal extract against bacteria.

\begin{tabular}{llll}
\hline Bacteria & L. ibericaL & P. ovata & Tetracycline \\
\hline B. coagulanse & $0^{\mathrm{a}}$ & $0^{\mathrm{a}}$ & $24.6 \pm 5^{\mathrm{d}}$ \\
B. antheracoid & $0^{\mathrm{a}}$ & $0^{\mathrm{a}}$ & $28 \pm 0^{\mathrm{e}}$ \\
B. cereus & $11.3 \pm 2.5^{\mathrm{b}}$ & $0^{\mathrm{a}}$ & $26 \pm 6^{\mathrm{de}}$ \\
B. sphericus & $15.3 \pm 3^{\mathrm{c}}$ & $0 \pm 16^{\mathrm{c}}$ & $41.3 \pm 1.1^{\mathrm{f}}$ \\
B. subtilis & $16.6 \pm 4.1^{\mathrm{c}}$ & $14.6 \pm 1.4^{\mathrm{c}}$ & $15.3 \pm 1.1^{\mathrm{c}}$ \\
E. coli O157 & $9.6 \pm 1.5^{\mathrm{b}}$ & $0^{\mathrm{a}}$ & $34.3 \pm 3^{\mathrm{fg}}$ \\
S. typhymoriumATCC3598 & $14.6 \pm 2.3^{\mathrm{c}}$ & $0^{\mathrm{a}}$ & $31.3 \pm 3^{\mathrm{e}}$ \\
S. liatica & $0^{\mathrm{a}}$ & $0^{\mathrm{a}}$ & $32.6 \pm 6.4^{\mathrm{ef}}$ \\
P. Flurossence & $0^{\mathrm{a}}$ & $0^{\mathrm{a}}$ & $33.3 \pm 4.1^{\mathrm{efg}}$ \\
Ps. Aeruginosa & $18.3 \pm 6.5^{\mathrm{d}}$ & $10 \pm 2^{\mathrm{b}}$ & $35 \pm 3^{\mathrm{g}}$ \\
\hline
\end{tabular}

Different letters indicate significant difference $(\mathrm{P}$-value $\leq 0.05)$

The results of the MIC and MBC methods are reported in Table 2 . These results indicate that $L$. iberica extract had the highest MIC and MBC effects against $P$. aeruginosa. The $P$. ovata extract had the highest MIC effect against $B$. sphaericus and $B$. subtilis. It is notable that $B$. sphaericus was affected most by $P$. ovata extract according to the MBC test.

Table 2. MIC and MBC $\left(\mathrm{mg}^{\mathrm{ml}} \mathrm{l}^{-1}\right)$ results of seed extracts.

\begin{tabular}{|c|c|c|c|c|c|c|}
\hline \multirow{2}{*}{ Bacteria } & \multicolumn{3}{|c|}{ MIC } & \multicolumn{3}{|c|}{ MBC } \\
\hline & P. ovata & L. iberica $\mathrm{L}$. & Tetracycline & P. ovate & L. iberica $\mathbf{L}$. & Tetracycline \\
\hline B. coagulanse & No & No & 0.39 & No & No & 3.125 \\
\hline B. antheracoid & No & 25 & 0.39 & No & No & 1.562 \\
\hline B. cereus & No & 12.5 & 0.39 & No & No & 1.562 \\
\hline B. sphericus & 6.25 & 6.25 & 0.195 & 12.5 & 25 & 0.39 \\
\hline B. subtilis & 6.25 & 6.25 & 1.562 & 25 & 50 & 3.125 \\
\hline E. coli 0157 & No & 25 & 0.195 & No & No & 0.78 \\
\hline S. typhymorium ATCC3598 & No & 6.25 & 0.39 & No & 25 & 1.562 \\
\hline S. liatica & No & No & 0.39 & No & No & 1.562 \\
\hline Ps. Flurossence & No & No & 0.39 & No & No & 0.78 \\
\hline Ps. Aeruginosa & 25 & 3.125 & 0.195 & No & 12.5 & 0.78 \\
\hline
\end{tabular}

No: no effect 


\section{Discussion}

Infectious diseases are one of the most common diseases in the world which impose huge financial burdens on human societies. Synthetic antibiotics have played an important role in the treatment of infectious diseases in recent decades. However, excessive use of these kinds of antibiotics and the problems associated with their antimicrobial resistance has led to an increase in the use of more herbal medicines as antibiotic alternatives $(21,22)$. The antimicrobial activity of plants is generally related to the presence of phenolic compounds, saponins, tannins and flavonoids in their structures. The antibacterial properties of these compounds are related to their effects on the cellular membrane or inhibition of structural enzymes (23).

According to the results of this study, the highest growth inhibition zone in the presence of $L$. iberica extract was related to $P$. aeruginosa with diameter of $18.3 \mathrm{~mm}$. It is notable that the inhibition zone diameter in the presence of $P$. ovata extract against $B$. subtilis was $14.1 \mathrm{~mm}$ (the difference was not statistically significant). The plant seed extracts did not have a significant effect on the growth inhibition zone of other bacteria.

The results of MIC and MBC tests showed that $L$. iberica extract had the highest effect on $P$. aeruginosa. In a similar study, the antibacterial effect of various extracts of herbs such as nettle (Urtica Dioicas) on B. subtilis, P. aeruginosa, E. coli and $S$. aureus was confirmed (24). L. iberica contains compounds such as $\beta$-cubebene, Linalool and Spathulenol (16). The medicinal plants and their metabolites such as linalool and thymol exterminate the microorganisms' membrane and cause liposaccharides leakage and increase the cytoplasmic membrane permeability to ATP. Eventually, the exit of ATP leads to the waste of cellular energy storage; and consequently causes cell death (25).

According to the results of this study, B. sphericus with the inhibition zone diameter of $16 \mathrm{~mm}$ was affected more than the other bacteria by the alcoholic extract of $P$. ovata. The inhibition zone diameter for B. Subtilis and $P$. aeruginosa were 14.6 and $10 \mathrm{~mm}$, respectively. Other bacteria were not affected by $P$. ovata extract.

The mechanism of plant compounds action on the prevention of bacterial growth involves the destructive effect on the cell wall, which results in the separation of the cell wall components and the exposure of the cell contents and ultimately the cell death. The antibiotic effect of $P$. ovata extract may be related to their secondary metabolites (26). The $P$. ovata extract had the highest MIC effect against $B$. sphericus and B. subtilis and the highest MBC effect against B. sphericus. The antibacterial effects of $P$. ovata extract have been previously studied against various bacteria such as $S$. aureus, $S$. pyogenes and $B$. bronchiseptica (15). Sharif et al. (2010) reported that the MIC of Plantago Psyllium against Staphylococcus aureus and Staphylococcus epidermidis were 20 and $18 \mathrm{~mm}$, respectively (27).

\section{Conclusion}

According to the results of this study, it can be concluded that the medicinal plant extracts of $P$. ovata and $L$. iberica are suitable for use in poultry feeds and human foods as herbal antibiotics. However, further studies are needed for the definitive administration of these extracts as the source of antibiotic plants.

\section{Acknowledgements}

The authors are grateful to Biotechnology Laboratory technicians of Persian Gulf University for their valuable technical assistance.

\section{Author Contributions}

The present study was funded by $\mathrm{HH}$ and NGH. HH and NGH were also involved in the collection of data, statistical analysis and drafting of the manuscript. LK read and approved the final manuscript.

\section{Conflict of Interest}

The authors declare that they have no competing interests.

\section{References}

1.Gautam R, Chapagin ML, Acharya A, Rayamajhi N, Shrestha S, Ansari S. Antimicrobial Susceptibility Patterns of Escherichia Coli From Various Clinical Sources. J Chitw Med Colle. 2013; 3(3): 14-17.

2. Ramakrishna P, Krishnamurthy V, Allavarapu R. Antibiotic Resistance in Non-humans and its Impact on Human Health. Rev art J Inter Medic and Denti. 2014; 2: 59-56.

3. Amin M, Rakhisi Z, Ahmady AZ. Isolation and Identification of Bacillus Species From Soil and Evaluation of Their Antibacterial Properties. Avicenna J Clin Microb Infec. 2015; 2(1): 10-13. PMID: 282839474

4. Sharma A, Satyanarayana T. Comparative Genomics of Bacillus species and its Relevance in Industrial Microbiology. Gen Insights. 2013; 6:25-36. PMID: 26217108

5. Moore ERB, Tindall BJ, Martins Dos Santos VAP, Pieper DH, Ramos JL, Palleroni NJ. Nonmedical: Pseudomonas. Prokaryotes. 2006; 6: 646-703. PMID: 227055540

6. Sichewo PR, Gono RK, Muzondiwa J, Mungadzi W. Isolation and identification of pathogenic bacteria in edible fish: A case study of rural aquaculture projects feeding livestock manure to fish in Zimbabwe. Int J Curr Microbiol. 2014; 3(11): 897-904. PMID: 299839965

7. Gales AC, Jones RN, Turnidge J, Ramphal R. Characterization of Pseudomonas aeruginosa isolates: occurrence rates, 
antimicrobial susceptibility patterns, and molecular typing in the global SENTRY Antimicrobial Surveillance Program, 1997-1999. Clin Infect Dis. 2001; 32: 146-55. PMID: 11320454

8. Calsamiglia S, Busquet M, Cardozo PW, Castillejos L, Ferret A. Invited review: Essential oils as modifiers of rumen microbial fermentation. J dai sci. 2007; 90: 2580-95. PMID: 17517698

9. Jernberg C, Lofmark S, Edlund C, Jansson JK. Long-term impacts of antibiotic exposure on the humanintestinal microbiota. Microbiolo. 2010; 11: 3216-23. PMID: 20705661

10. O'Neill J, Antimicrobials in agriculture and the environment: reducing unnecessary use and waste. 2015: Rev Antimicro Resist.

11. Al-Mariri A, Safi M. In Vitro Antibacterial Activity of Several Plant Extracts and Oils against Some Gram-Negative Bacteria. Iran J Med. 2014; 39:36-43. PMID: 24453392

12. Karimzadeh G, Omidbaigi R. Growth and Seed Characteristics of Isabgol (Plantago ovata Forsk) as Influenced by some Environmental Factors. J Agric Sci Technol. 2004; 6: 103-110. PMID: 239374230

13. Bernedo N, Garcia M, Gastaminza G, Femandez E, Bartolome B, Alqorta J, Munoz D. Allergy to laxative compound (Plantago ovata seed) among health care professionals. J Investig Allergol Clini Immunol. 2008; 18(3): 181-9. PMID: 18564629

14. Singh S, Singh R, Kumar N, Kumar R. Wound healing activity of ethanolic extract of Plantago Ovata (Ispaghula) seeds. J Appli Pharm Scien. 2011; 1(7):108-111. PMID: 123456789

15. Motamedi H, Darabpour E, Gholipour M, Sayyed Nejad SM Antibacterial effect of ethanolic and methanolic extracts of Plantago ovata and Oliveria decumbensendemic in Iran against some pathogenic bacteria. Inter J Pharmacolo. 2010; 6(2): 117-22. PMID: 20103191740

16. Khosravi Dehaghi N, Gohari AR, Sadat-Ebrahimi SS, Naghdi Badi H, Amanzadeh Y. Phytochemistry and antioxidant activity of Lallemantia iberica aerial parts. Res J Pharmacog. 2016; 3(3):2734

17. Boskovic M, Zdravkovic N, Ivanovic J, Janjic J, Djordjevic J, Starcevic M, Baltic MZ. Antimicrobial activity of thyme (Tymus vulgaris) and oregano (Origanum vulgare) essential oils against some food-borne microorganisms. Procedia Food Sci. 2015; 5(2015):18-21. PMID: 283895954
18. Habibi H, Ghahtan N, Kohanmoo, MA, Eskandari F. Chemical Composition and Antibacterial Effect of Medicinal Plants against Some Food-Borne Pathogens. RMM. 2017; 5(2): 14-21.

19. Al-hajj NQM, Wang HX, Ma C, Lou Z, Bashari M, Thabit R. Antimicrobial and antioxidant activities of the essential oils of some aromatic medicinal plants (Pulicaria inuloides-Asteraceae and Ocimum forskolei-Lamiaceae). Trop J Pharm Res. 2014; 13(8):1287-93. PMID: 267031992

20. Cimanga K, Kambu K, Tona L, Apers S, De Bruyne T, Hermans N, et al. Correlation between chemical composition and antibacterial activity of essential oils of some aromatic medicinal plants growing in the Democratic Republic of Congo. J Ethnophar. 2002; 79: 213-20. PMID: 11801384

21. Ateş DA, Erdoğrul ÖT. Antimicrobial activities of various medicinal and commercial plant extracts. Turk J Biol. 2003; 27: 157-62. PMID: 284147769

22. Burt S. Essential oils: their antibacterial properties and potential applications in foods a review. Inter J Food Microbiolo. 2004; 94: 223-53. PMID: 15246235

23. Soltani M, Ghodratnama M, Taheri Mirghaed, A, Zargar A, Rouhollahi SH. The Effect Of Zataria Multiflora Boiss. And Rosmarinus Officinalis Essential Oil On Streptococcus Iniae Isolated From Rainbow Trout Farms. J Veterin Microbiol. 2013; 9(26): 1-13. PMID: 285329357

24. Majd A, Mehrabian S, Zohreh J. The Study Of Antimicrobial Effects Of Urtica Dioicas Extract. Iran J Medic Arom Plan. 2003; 19(3): 287-93. PMID: 120106

25. Mahboubi M, Feizabadi MM, Haghi GH, Hossein $H$ Antimicrobial activity and chemical composition of essential oil from Oliveria decumbens Vent. Iran J Med Aromc Plan. 2008; 24(1): 56-65. PMID: 112865

26. Windisch W, Schedle K, Plitzner C, Kroismayr A. Use of Phytogenic Products as Feed Additives for Swine and Poultry. J Animal Sci. 2014; 86: 140-48. PMID: 18073277

27. Sharifi A, Naghmachi M, Jahedi S, Khosravani SAM. A Study on Antimicrobial Effects of Plantago Psyllium. Armaghanedanesh. 2010; 16(2): 191-9 